\title{
FAKTOR-FAKTOR YANG MEMPENGARUHI PEMBELIAN APARTEMEN MEWAH, THE STATURE JAKARTA
}

\author{
Anastasia Inesencia \\ Program Studi Magister Manajemen Universitas Tarumanagara \\ anastasiainesencia@yahoo.com
}

Masuk : 07-12-2019, revisi : 21-12-2019 diterima untuk diterbitkan : 21-12-2019

\begin{abstract}
The need for a home is one of the basic human needs. Currently home ownership is not only intended for the fulfillment of basic needs only, but has become an interesting investment alternative in Jakarta, one of the centers of economic growth with the rate of population increase is quite high in Indonesia. Population growth that occurs either naturally or through the process of urbanization led to a growth in demand for residential houses. It is boosting the development of the city of Jakarta Property in good simple house to luxury Property. The research result is consumer property in the city of Jakarta, in buying luxury property prefers factors.
\end{abstract}

Keywords : Apartment, Luxury, Urbanization, Factor Analysis

\begin{abstract}
Abstrak : Kebutuhan akan rumah merupakan salah satu kebutuhan dasar bagi manusia. Saat ini kepemilikan rumah tidak hanya ditujukan untuk pemenuhan kebutuhan pokok, melainkan telah menjadi suatu alternatif investasi yang cukup menarik Kota Jakarta yang merupakan pusat pertumbuhan ekonomi dengan laju pertambahan penduduk yang cukup tinggi di Indonesia. Pertambahan penduduk baik secara alamiah maupun melalui proses urbanisasi menyebabkan pertumbuhan pada permintaan rumah tinggal. Hal ini mendorong pertumbuhan pembangunan Property di Kota Jakarta baik rumah sederhana hingga Property mewah. Tujuan penelitian ini adalah untuk mengetahui faktor-faktor apa yang menjadi pertimbangan konsumen dalam membeli properti mewah di Jakarta.
\end{abstract}

Kata Kunci : Apartemen, Mewah, Urbanisasi, Analisa Faktor

\section{Latar Belakang}

Jakarta merupakan ibukota Negara Indonesia yang tentunya menjadi salah satu pusat bisnis yang paling diminati banyak orang dari berbagai daerah. Selain itu pertumbuhan ekonomi disuatu negara menjadi alat ukur untuk melihat atau menganalisa seberapa jauh tingkat perkembangan perekonomian di negara tersebut.

Banyak orang berpendapat bahwa lebih mudah mendapatkan pekerjaan dengan gaji tinggi di kota besar seperti Jakarta sehingga menyebabkan pertumbuhan penduduk di Jakarta yang semakin meningkat. Semakin bertambahnya penduduk tentunya berdampak pada meningkatnya kebutuhan tempat tinggal di Jakarta. Dengan lahan yang semakin terbatas dan melambungnya harga tanah di Jakarta, maka hunian vertikalpun menjadi salah satu alternative dalam masalah ini.

Disisi lain, properti di Indonesia saat ini tidak hanya menjadi suatu kebutuhan pokok namun juga merupakan bentuk investasi paling menjanjikan dimana harganya yang cenderung tetap naik dari waktu ke waktu. Investasi merupakan kunci utama untuk mencapai peningkatan pertumbuhan ekonomi yang tercermin dari kemampuannya meningkatkan laju pertumbuhan dan tingkat pendapatan. Semakin besar investasi di suatu negara, maka semakin besar pula tingkat pertumbuhan ekonomi yang bisa dicapai. Dengan demikian pertumbuhan ekonomi merupakan fungsi investasi (Haryanto, 2005). Saat ini para investor memilih properti untuk dijadikan asset investasi jangka panjang. Sebagai pengembang lahan pastinya harus mengerti 
bahwa banyak faktor yang dapat mempengaruhi konsumen ketika memilih produk properti, baik dari selera maupun kebutuhan yang dicari.

New development yang dilakukan oleh pengembang harus memberikan added value terhadap lahan dan masyarakat sehingga secara tidak langsung akan meningkatkan nilai jual terhadap lahan yang telah dikembangkan tersebut. Setiap lahan yang dikembangkan pada akhirnya akan memiliki sebuah icon atau image yang menentukan target pasar dari properti tersebut, salah satunya target pasar properti premium yang umumnya selalu menjadi bagian dalam new development skala besar.

Beberapa kawasan di wilayah Jakarta menjadi sangat eksklusif khususnya wilayah segitiga emas (golden triangle) Jakarta yakni Sudirman, Thamrin dan Kuningan yang menjadi buruan khususnya para investor besar untuk mengembangkan bisnisnya. Meski begitu, hal ini justru memberikan potensi pasar baru untuk kawasan lainnya, seperti area ring satu, tepatnya di wilayah pusat pemerintahan di sekitaran Monumen Nasional (Monas).

Tingginya harga properti di kawasan ini dianggap telah melewati teori bisnis yang berpegang pada keuntungan finansial semata, dan mengarah pada ego dan kebanggaan akan memiliki atau tinggal di kawasan nomor satu di Jakarta. Namun pertimbangan utama yang mendasari para pembeli properti premium ini belum diketahui secara pasti sehingga hal ini mendorong penulis untuk melakukan penelitian mengenai faktor-faktor yang mempengaruhi nilai suatu apartemen premium di Jakarta.

\section{Tujuan Penelitian}

Penelitian ini bertujuan untuk mengetahui faktor-faktor yang mempengaruhi pembelian apartemen mewah, The Stature Jakarta sehingga untuk kedepannya sebagai konsumen dapat memilih properti yang tepat baik sebagai investasi maupun untuk tempat tinggal pribadi dan sebagai pengembang suatu kawasan dapat lebih menyadari apa yang menjadi kebutuhan konsumennya.

\section{TINJAUAN PUSTAKA}

\section{Teori Penawaran dan Permintaan}

Teori Penawaran dan Permintaan (supply and demand) dalam ilmu ekonomi adalah penggambaran atas hubungan-hubungan di pasar, antara para calon pembeli dan penjual dari suatu barang. Model penawaran dan permintaan digunakan untuk menentukan harga dan kuantitas yang terjual di pasar. Model ini sangat penting untuk melakukan analisis ekonomi mikro terhadap perilaku serta interaksi para pembeli dan penjual. Model ini memperkirakan bahwa dalam suatu pasar yang kompetitif, harga akan berfungsi sebagai penyeimbang antara kuantitas yang diminta oleh konsumen dan kuantitas yang ditawarkan oleh produsen, sehingga terciptalah keseimbangan ekonomi antara harga dan kuantitas. Model ini mengakomodasi kemungkinan adanya faktor-faktor yang dapat mengubah keseimbangan, yang kemudian akan ditampilkan dalam bentuk terjadinya pergeseran dari permintaan atau penawaran (Mankiw,2004).

Penawaran adalah jumlah barang atau jasa yang bersedia dan dapat dijual oleh penjual pada berbagai tingkat harga dan pada waktu tertentu. Beberapa faktor yang mempengaruhi penawaran:

1. Harga barang itu sendiri

2. Harga sumber produksi

3. Tingkat produksi

4. Ekspektasi/perkiraan

Permintaan adalah jumlah barang atau jasa yang ingin dan mampu dibeli oleh konsumen, pada berbagai tingkat harga dan pada waktu tertentu. Beberapa faktor yang mempengaruhi permintaan:

1. Harga barang itu sendiri 
2. Harga barang lain yang berkaitan

3. Tingkat pendapatan

4. Selera konsumen

5. Ekspektasi/perkiraan

Ketika seorang konsumen memutuskan untuk membeli sebuah produk, pada dasarnya konsumen saat itu sedang berada dalam tahapan buyer decision process. Tahapan yang dilalui oleh konsumen tersebut pertama kali diperkenalkan oleh Engel, Blackwell dan Kollat (1968) yang kemudian dijelaskan lebih lanjut oleh Philip Kotler dalam bukunya Marketing Management Millenium Edition, 2000, (1) problem recognition dimana konsumen menyadari adanya masalah atau kebutuhan (2) information search dimulai saat konsumen secara aktif melakukan pencarian informasi mengenai produk yang dapat mengatasi permasalahan yang dialami atau dengan kata lain untuk memenuhi kebutuhannya (3) evaluation of alternatives yaitu konsumen mengevaluasi berbagai alternative/pilihan produk untuk mengetahui produk mana yang pada akhirnya akan dipilih, dimana dalam tahap ini konsumen akan melihat produk sebagai satu kesatuan dari berbagai atribut yang dapat memberikan manfaat bagi konsumen (4) dalam tahapan purchase decision konsumen akan melakukan pengambilan keputusan untuk membeli produk atau tidak setelah melakukan evaluasi terhadap beberapa alternative/pilihan di tahap sebelumnya dimana ternyata keputusan konsumen dalam tahapan ini bias dipengaruhi oleh orang lain yang merupakan influencer-nya (5) setelah membeli produk konsumen akan masuk ke tahap akhir yaitu postpurchase behaviour yang bias berupa kepuasan atau ketidakpuasan terhadap produk yang dikonsumsi atau sebut saja postpurchase satisfaction, kemudian postpurchase action, sampai kemudian postpurchase use and disposal.

Tingkat involvement konsumen dalam masing-masing tahapan buyer dicision process akan berbeda. Sebagai contoh, seorang konsumen bias saja tidak melewati tahapan 1, 2 dan 3 dan langsung masuk ke tahap 4 dimana konsumen tersebut memutuskan untuk membeli sebuah produk.

\section{Kriteria Pemilihan Apartemen}

Berikut aspek yang merupakan kriteria konsumen dalam mengambil keputusan dalam pemilihan apartemen (Schmitz, A.2000.Multifamily Housing Development Handbook. Urban Land Institute. Washington):

1. Rekam Jejak Developer

2. Sertifikat Bangunan

3. Fasilitas Pendukung

4. Faktor Keamanan

5. Fasilitas Parkir

6. Lokasi Properti

\section{Analisis dan Pembahasan}

\section{Uji Reliabilitas}

Setelah mendapatkan penjelasan mengenai uji reabilitas pada bab sebelumnya dapat diketahui bahwa tujuan dari uji reliabilitas adalah untuk mengetahui apakah hasil dari penyebaran kuesioner tersebut dapat mengukur secara konsisten mengenai sasaran yang diukur atau konsistensi skor yang dicapai jika dilakukan tes secara berulang-ulang. Selain itu dilakukan tes validitas untuk mengetahui apakah tiap-tiap faktor tersebut valid atau tidak. Hasil lengkap pada pengolahan data menggunakan Uji Reliabilitas terhadap faktor-faktor yang mempengaruhi pembelian apartemen mewah The Stature Jakarta.

\section{Metode Analisis Faktor}

Setelah mendapatkan penjelasan mengenai metode analisis faktor pada bab sebelumnya dapat diketahui bahwa tujuan dari metode analisis faktor adalah untuk mengelompokan faktor- 
faktor yang ada agar lebih sederhana. Selain itu tujuan lain dari analisis faktor adalah untuk melihat faktor yang ada valid atau tidak untuk dilakukan pengelompokan. Hasil lengkap pada pengolahan data menggunakan Metode Analisis Faktor untuk faktor-faktor yang mempengaruhi pembelian apartemen mewah The Stature Jakarta.

\section{Pembahasan}

Pada sub-bab ini akan dijelaskan mengenai hasil analisis data menggunakan 2 (dua) metode yaitu: metode-metode Reliabilitas, dan metode Analisis Faktor.

\section{Hasil Output Uji Reliabilitas}

Dalam pengujian reliabilitas diuji 1 variabel, yaitu variabel mengenai factor-faktor yang mempengaruhi pembelian apartemen mewah The Stature, Jakarta. Analisis hasil output uji Reliabilitas adalah sebagai berikut:

\section{Tabel 4.1}

\section{Hasil Penilaian Cronbach's Alpha}

Reliability Statistics

\begin{tabular}{|c|r|}
\hline $\begin{array}{c}\text { Cronbach's } \\
\text { Alpha }\end{array}$ & N of Items \\
\hline .821 & 15 \\
\hline
\end{tabular}

Pada uji reliabilitas ini hal terpenting yang harus dilakukan adalah untuk mencari nilai cronbach's alpha, dimana syarat untuk suatu data reliabel atau tidak harus memenuhi syarat nilai cronbach's alpha yaitu 0,7 . Nilai cronbach's alpha pada pengujian faktor-faktor yang mempengaruhi pembelian apartemen The Stature Jakarta adalah 0,821 sehingga data yang diperoleh dalam kuesioner adalah reliabel.

Tabel 4.2

Hasil Penilaian Corrected Item-Total Correlation Item-Total Statistics

\begin{tabular}{|l|r|r|r|r|}
\hline & $\begin{array}{c}\text { Scale Mean if } \\
\text { Item Deleted }\end{array}$ & $\begin{array}{c}\text { Scale } \\
\text { Variance if } \\
\text { Item Deleted }\end{array}$ & $\begin{array}{c}\text { Corrected } \\
\text { Item-Total } \\
\text { Correlation }\end{array}$ & $\begin{array}{c}\text { Cronbach's } \\
\text { Alpha if Item } \\
\text { Deleted }\end{array}$ \\
\hline A2 & 25.0000 & 59.310 & .647 & .796 \\
A3 & 24.4667 & 60.671 & .664 & .796 \\
A5 & 24.7667 & 61.771 & .525 & .810 \\
A6 & 24.7000 & 57.183 & .667 & .792 \\
A8 & 25.4000 & 58.800 & .752 & .786 \\
A9 & 24.7000 & 62.424 & .411 & .824 \\
A14 & 24.7667 & 62.323 & .404 & .825 \\
A15 & 25.0000 & 62.000 & .401 & .826 \\
\hline
\end{tabular}

\section{Analisis Hasil Output Analisis Faktor}

Pengujian dengan metode Analisis Faktor diperlukan untuk menyederhanakan atau mengelompokkan faktor-faktor yang ada menjadi beberapa kelompok saja.

Pengujian dengan menggunakkan metode Analisis Faktor ini mendapatkan nilai 0,594 pada KMO and Bartlett's Test sehingga telah memenuhi syarat yaitu harus melenihi 0,5. Hasil penilaian KMO and Bartlett's Test dapat dilihat pada Tabel 4.3.

Tabel 4.3

\section{Hasil Penilaian KMO and Bartlett's Test} KMO and Bartlett's Test

\begin{tabular}{|ll|r|}
\hline Kaiser-Meyer-Olkin Measure of Sampling Adequacy. & .594 \\
Bartlett's Test of & Approx. Chi-Square & 123.468 \\
Sphericity & df & 36 \\
& Sig. & .000 \\
\hline
\end{tabular}


Pengujian selanjutnya adalah melihat nilai pada Anti-Image Matrices untuk melihat apakah variable tersebut valid atau tidak dengan melihat angka MSA harus diatas 0,5. Kemudian nilai extraction pada tabel communalities juga harus lebih besar dari 0,5. Hasil penilaian Anti-Image Matrices dapat dilihat pada table 4.4. Hasil Extraction dapat dilihat pada table 4.5.

Tabel 4.4

Hasil Peniliaian Anti-Image Matrices

Anti-image Matrices

\begin{tabular}{|c|c|c|c|c|c|c|c|c|c|}
\hline & & $\mathrm{A} 2$ & A3 & A5 & A6 & A8 & A9 & A14 & A15 \\
\hline \multirow[t]{8}{*}{ Anti-image Covariance } & $\mathrm{A} 2$ & .426 & -.088 & .109 & .084 & -.154 & -.116 & -.025 & -.013 \\
\hline & A3 & -.088 & .341 & -.135 & -.034 & -.066 & .036 & .015 & -130 \\
\hline & A5 & .109 & -.135 & .521 & .029 & -.094 & .018 & -.012 & -.115 \\
\hline & A6 & .084 & -.034 & .029 & .334 & -.151 & -.205 & -.060 & .087 \\
\hline & A8 & -.154 & -.066 & -.094 & -.151 & .213 & .105 & -.029 & -.026 \\
\hline & $A 9$ & -.116 & .036 & .018 & -.205 & .105 & .490 & -.201 & -.168 \\
\hline & A14 & -.025 & .015 & -.012 & -.060 & .029 & -.201 & .657 & .108 \\
\hline & $\mathrm{A} 15$ & -.013 & -.130 & -.115 & .087 & -.026 & -.168 & .108 & .609 \\
\hline \multirow[t]{8}{*}{ Anti-image Correlation } & $A 2$ & $.748^{\mathrm{a}}$ & -.231 & .232 & .222 &. .512 & -.255 & -.047 & -.025 \\
\hline & A3 & -.231 & $.854^{\mathrm{a}}$ & -.321 & -.102 & -.245 & .088 & .033 & -.285 \\
\hline & A5 & .232 & -.321 & $.798^{\mathrm{a}}$ & .070 & -.283 & .035 & -.020 & -205 \\
\hline & $A 6$ & .222 & -.102 & .070 & $.689^{\mathrm{a}}$ & -.568 &. .507 & -.127 & .192 \\
\hline & A8 & -.512 & -.245 & -.283 & -.568 & $.714^{\mathrm{a}}$ & .324 & -.078 & -.073 \\
\hline & A9 & -.255 & .088 & .035 & -.507 & .324 & $.544^{\mathrm{a}}$ & -355 & -307 \\
\hline & $\mathrm{A} 14$ & -.047 & .033 & -.020 & -.127 & -.078 & -.355 & $.791^{\mathrm{a}}$ & .170 \\
\hline & $\mathrm{A} 15$ & -.025 & -.285 & -.205 & .192 & .073 & -.307 & .170 & $.752^{\mathrm{a}}$ \\
\hline
\end{tabular}

Tabel 4.5

Tabel Hasil Extraction

Communalities

\begin{tabular}{|l|r|r|}
\hline & Initial & Extraction \\
\hline $\mathrm{A} 2$ & 1.000 & .576 \\
$\mathrm{~A} 3$ & 1.000 & .802 \\
$\mathrm{~A} 5$ & 1.000 & .635 \\
$\mathrm{~A} 6$ & 1.000 & .717 \\
$\mathrm{~A} 8$ & 1.000 & .797 \\
$\mathrm{~A} 9$ & 1.000 & .669 \\
$\mathrm{~A} 14$ & 1.000 & .678 \\
$\mathrm{~A} 15$ & 1.000 & .687 \\
\hline
\end{tabular}

Tabel 4.6

Pengelompokkan pada Rotated Component Matrix

Rotated Component Matrix ${ }^{a}$

\begin{tabular}{|l|c|r|}
\hline \multirow{2}{*}{} & \multicolumn{2}{|c|}{ Component } \\
\cline { 2 - 3 } & 1 & \multicolumn{1}{c|}{2} \\
\hline A3 & .880 & .169 \\
A8 & .806 & .384 \\
A5 & .796 & -.033 \\
A15 & .698 & -.006 \\
A2 & .635 & .416 \\
A14 & .003 & .824 \\
A9 & .049 & .817 \\
A6 & .425 & .732 \\
\hline
\end{tabular}




\section{Kesimpulan}

Dengan metode Tabel 4.6, faktor-faktor tersebut dapat dikelompokkan menjadi dua kelompok yaitu kelompok faktor eksternal dan kelompok faktor internal.

1. Kelompok pertama (Faktor Eksternal)

Kelompok ini terdiri dari:

a. A3 (Kemudahan akses seperti jarak menuju lokasi transportasi umum dan jarak ke pintu toll)

b. A8 (Fasilitas penunjang seperti rumah sakit, perbankan, restoran dan perkantoran maupun sekolah bertaraf internasional)

c. A5 (Keamanan dan kenyamanan di lokasi apartemen)

d. A14 (Kredibilitas pengembang kawasan)

e. A15 (Fasilitas umum yang tersedia dengan baik seperti pedestrian, lebar jalan utama, penataan taman kota dll.)

f. A2 (Komunitas masyarakat sosial kelas atas)

2. Kelompok kedua (Faktor Internal)

Kelompok ini terdiri dari:

a. A9 (Desain arsitektur dan interior dari perancang terkemuka.)

b. A6 (Kelengkapan fasilitas dan ketersediaan ruang terbuka hijau)

Dari hasil yang didapatkan dapat disimpulkan bahwa ada 8 faktor utama yang secara dominan mempengaruhi pembelian sebuah unit apartemen mewah yang pada penulisan ini difokuskan pada salah satu apartemen di pusat Jakarta, The Stature.

\section{Daftar Pustaka}

Kotler, Philip dan K.L, Keller. 2000. Manajemen Pemasaran. Jilid I. Edisi ke 13. Erlangga, Jakarta.

Mahardini Ismi. 2012. Pengaruh Harga, Pendapatan, Lokasi dan Fasilitas Terhadap Permintaan Rumah Sederhana (Studi Kasus Puri Dinar Mas Semarang). Skripsi. FE Undip. http://eprints.undip.ac.id/36000/1/ MAHARDINI.pdf. tgl akses 12 Oktober 2015

Maoludyo F.T. dan Aprianingsih A. (2015), "Factors Influencing Consumer Buying Intention for Housing Unit in Depok", Journal of Business and Management, Vol. 4, No. 4, 2015: 484-493

Peter Lie. 2015. Studi Motivasi Pembeli Properti Premium (Kasus Apartemen Kelas Atas di SCBD, Jakarta Selatan) Tesis MT Untar.

Primananda, Agustinus. 2010. Faktor-faktor yang Mempengaruhi Konsumen Dalam Membeli Rumah (Studi pada Perumahan Bukit Semarang) Skripsi FE Undip. https://core.ac.uk/download/pdf/11722103.pdf. tgl akses 12 Oktober 2015.

Rahma, Intan, sari. 2010. Analisis faktor-faktor yang Mempengaruhi Permintaan Perumahan Tipe Cluster (Studi Kasus Perumahan Taman Sari di Kota Semarang). Skripsi FE Undip. https://core.ac.uk/download/ files/379/11722121.pdf . Akses tgl 10 Oktober 2015. 